Если же обучающийся запоминает фразы с помощью мнемонических методов, то эти фразы сами крутятся в голове, как навязчивые ритмы знакомых песен. Начинают сниться сны на изучаемом языке - это и будет являться верным признаком качественного запоминания слов и фраз.

Один из эффективных факторов от применения мнемотехники при обучении английскому языку является то, что появляется интерес к изучению иностранного языка. А при его изучении такой мотивирующий фактор как заинтересованность крайне необходим и, следовательно, процесс обучения носит продуктивный и продолжительный характер.

$$
* * *
$$

1. Артемов В.А. Психология обучения иностранным языкам. - М.: Просвещение, 1969. - 279 с.

2. Беляев Б.В. Очерки по психологии обучения иностранным языкам. 2-е изд. - М.: Просвещение, 1965. - $229 \mathrm{c}$.

3. Блонский П.П. Память и мышление. - Соч.-М.,1979, т. 2, с. 118-340.

4. Зимняя И.А. Психология обучения иностранным языкам в школе. М.: Просвещение, 1991. - 222 с. - (Библиотека учителя иностранного языка).

5. Рогов Е.И. Общая психология: Курс лекций для первой ступени образования. / Сост. Е.И. Рогов. М.: Гуманит. Изд. Центр ВЛАДОС, 2002. - 448 с.

6. Словарь практического психолога / Сост. С.Ю. Головин: Харвест; Минск; 1998

7. Черемошкина, Л.В. Психология памяти. - М.: Академия, 2002. -368c

\title{
Григорян А.Г. \\ Использование интерактивных методов при обучении страноведению в рамках дисциплины «Иностранный язык» в средней школе
}

МКОУ СОШ№ 1

(Россия, Сосенский)

doi 10.18411/spc-04-10-2017-03

idsp 000001:spc-04-10-2017-03

Развитие социально-экономических отношений в современном мире выдвигает новые требованияи ставит новые задачи в обучении иностранному языку в средней школе. В настоящее время изучение иностранного языка невозможно представить без изучения культуры, традиций страны изучаемого языка, так как иностранный язык очень тесно переплетен с культурными особенностями англоговорящих стран. Исследования многих российских ученых (Верещагина Е.М.,Костомарова В.Г. «Лингвострановедение в преподавании русского языка как иностранного», ТерМинасовой С.Г. «Язык и межкультурная коммуникация», Н.Д.Арутюновой «Язык и мир человека», В.А.Масловой «Язык и мир человека») показывают, что если обучение иностранному языку ограничивать обучением языковой системе или овладению только коммуникативной речевой компетенцией, знания языка у обучающихся будут неполноценными, поэтому в настоящее время, при преподавании иностранного языка все больше и больше внимания уделяют изучению культурным традициям, истории, менталитетам народов изучаемого языка, особенностям национального характера, что подразумевает не простое получение информации об изучаемых странах, а формирование способностей и умений в общении и обращении с другими культурами.

Как говорит С.Г. Тер- Минасова:«Каждый урок иностранного языка — это перекресток культур, это практика межкультурной коммуникации, потому что каждое иностранное слово отражает иностранный мир и иностранную культуру: за каждым словом стоит обусловленное национальным сознанием представление о мире».

В настоящем времени изучение культур и традиций англоязычных стран приобретает иной характер, так как современный мир характеризуется сплетением культур разных стран или так называемым процессом глобализации. Глобализация 
находит отражение в образовательном процессе, ставя перед школой новые требования, a английский язык становится общепринятым языком мирового общества. Этим обусловлены изменения, которые происходят в методике преподавания английского языка, ориентируя обучение языку на такие условия коммуникации, которые подразумевают усвоение внеязыковой информации о различных материальных и духовных условиях существования других народов и стран, знакомство с историческими и политическими особенностями, культурой, экономической системой народов-носителей языка.

Следовательно, перед педагогами стоит задача выбора методов преподавания, которые не только наилучшим образом познакомят обучающихся с культурологическим аспектом иноязычных стран, так как обучающиеся на каждом уроке иностранного языка непроизвольно сталкиваются с культурой страны изучаемого языка, но и будут способствовать повышению мотивации к изучению иностранного языка.

Известно, что педагоги зачастую сталкиваются с низкой мотивацией обучающихся. Однако, существует множество факторов, которые влияют на мотивацию в той или иной степени. Это и педагогический такт, и мастерство педагога, которое позволяет сформировать позитивное отношение обучающихся к предмету, а также осознать актуальность изучения иностранного языка, и внеклассная деятельность по предмету, которая развивает творческую активность обучающихся. Но все же главным орудием решения этой проблемы является применение эффективных образовательных технологий, которые будут способствовать повышению познавательного интереса обучающихся к изучению иностранного языка и, следовательно, на формирование коммуникативной компетенции. Анализ методической литературы по данной проблеме позволяет выявлять достаточно большое количество исследований, посвященных, как уже существующим методам преподавания английского языка, так и к разработке новых технологий. Для реализации актуальных требований современного образования ученые и передовые педагоги проводят многочисленные исследования, разрабатывают наиболее эффективные методы и формы обучения, технологии, среди них занимает немаловажное место интерактивные методы и приемы обучения.

Интерактивные технологии, нацелены на активное взаимодействие обучающихся друг с другом, в ходе которых они обмениваются знаниями, идеями, находят пути решения проблемы, добиваются поставленной цели, экспериментируют с разными видами работ в непринужденной обстановке.

Это в свою очередь позволяет более эффективно решить общеобразовательные, практические, воспитательные задачи. Знакомство с национальной культурой, традициями, историей, литературой, политической системой Великобритании и США, а также других англоязычных стран, позволяет расширить кругозор обучающихся, развивает их внутренний мир и интеллект, воспитывает любовь и уважение к культуре, традициям, обычаям, истории страны изучаемого языка. Лакоценина Т.П. отмечает, что интерактивные методы обучения предполагают такое взаимодействие учителя и обучающихся, которое ориентирует личность на развитие ее творческих способностей, выработку умения выбирать ситуацию, нацеливают на деятельность, стимулирующую «изобретательство» и «открывательство».

По определению Ступиной С.Б. «Интерактивный метод это способ познания, осуществляемый в формах совместной деятельности обучающихся, при котором все участники образовательного процесса взаимодействуют друг с другом, обмениваются информацией, решают проблемы совместно, моделируют ситуации, оценивают 
действия коллег и свое собственное поведение, погружаются в реальную атмосферу делового сотрудничества по разрешению проблем».

Н. Суворова определяет интерактивное обучение как «диалоговое обучение, в ходе которого осуществляется взаимодействие ученика и учителя. Одна из целей интерактивных технологий состоит в создании комфортных условий обучения, таких, при которых обучающийся чувствует свою успешность, свою интеллектуальную состоятельность, что делает продуктивным сам процесс обучения. Суть интерактивного обучения состоит в том, чтобы организовать учебный процесс таким образом, чтобы практически все обучающиеся оказались вовлеченными в процесс познания, имели возможность понимать и рефлектировать по поводу того, что они знают и думают.

На сегодняшний день существует огромное разнообразие интерактивных методов. Среди них можно отметить творческие задания, обучающие игры: ролевые игры, имитации, деловые игры и образовательные игры, проектная методика, социальные проекты, соревнования, радио и газеты, фильмы, спектакли, выставки, представления, песни и сказки; групповое обсуждение, видеоконференция, обсуждение сложных и дискуссионных вопросов и проблем («Шкала мнений)», ПОПС-формула, проективные техники, «Один - вдвоём - все вместе», «Смени позицию», «Карусель», «Дискуссия в стиле телевизионного ток-шоу», дебаты, симпозиум);разрешение проблем («Дерево решений», «Мозговой штурм», «Анализ казусов», «Переговоры и медиация», «Лестницы и змейки»).

Применяя интерактивные технологии, следует учитывать возрастные особенности и интересы обучающихся и подбирать их в соответствии с их возрастом. Так как интерактивные методы приемлемые в начальных классах не целесообразно применять в среднем звене, всредней школе у обучающихся происходят психологические и физические изменения, наблюдается личностный рост, развивается логическое мышление, заметен существенный рост познавательного интереса, наблюдается рост сознания и самосознания, активизируется логическая память. Подросток стремится к самостоятельности в умственной деятельности. Следовательно, педагог, подбирая те или иные технологии должен ориентироваться на возраст детей

Какие же интерактивные методы может применить учитель при обучении страноведению. Педагоги могут использовать в своей работе уже существующие интерактивные приемы, а так же сами разрабатывать новые интерактивные методы. Одну изнаиболее эффективных технологий = ролевую игру -можно использовать при изучении разных страноведческих тем. Например, ролевую игру«Учитель-ученик» можно применить при изучении таких тем как «Школьное образование в Англии».Ролевые игры«Экскурсовод -туристы» или «Местный житель - иностранец» при изучении городов Великобритании.

При изучении темы «Достопримечательности Великобритании» можно организовать виртуальную экскурсию.

Использование интерактивных технологий при обучении страноведению эффективно отражается на учебном процессе, так как позволяет обучающимся погружаться в языковую среду, расширять страноведческие знания и формировать социокультурные компетенции, тем самым стимулируя языковое общение, воспитывая положительное отношение к иностранному языку, к культуре, истории, традициям народа носителя языка. Правильно подобранные интерактивные методы развивают образное мышление обучающихся, ведут к более осознанному владению языком как средству общения, повышают их активность и заинтересованность и стимулируют взаимодействие учителя с обучающимися. А одновременное изучение иностранного языка и культуры дает возможность комбинировать элементы страноведения с 
изучением грамматических структур и лексики ,которые выступают не только как средства коммуникации, но и как способы введения обучающихся в незнакомую для них действительность.

$$
* * *
$$

1. С. Г. Тер-Минасова Язык и межкультурная коммуникация. 2000г.

2. Лакоценина Т.П., Алимова Е.Е., Оганезова Л.М. Нестандартные уроки.- Издательство «Учитель», 2007.

3. Суворова Н.А. Интерактивные методы: новые подходы.2005г.

4. Маслова В.А Лингвокультурология. 2001г.Москва

5. Ступина С.Б. Технологии интерактивного обучения в высшей школе: учеб.-метод. пособие. Саратов: Наука, 2009.

\section{Корнеева Р.Ш., Романова Г.Н. Преимущества виртуальной среды MOODLE при использовании в учебном процессе}

Казанский Наџиональный Исследовательский Технологический Университет (КХТИ) (Россия, Сосенский)

doi 10.18411/spc-04-10-2017-04

idsp 000001:spc-04-10-2017-04

Заочная форма профессиональной подготовки и переподготовки специалистов является неотъемлемой частью среднего и высшего профессионального образования современной России.

Заочная форма получения профессионального образования, сочетающая в себе черты самообучения и очной учебы, характеризуется периодичностью. В одном из периодов происходит получение базы знаний, обучающей литературы и её изучение (установочная сессия), во втором - производится проверка усвоенного материала (зачётно-экзаменационная сессия). При этом эти периоды заметно отстают, друг от друга по времени (обычно от нескольких месяцев до года).

Классическое заочное обучение использует поточный принцип: единый для всех студентов образовательный план, общие сроки сдачи контрольных и курсовых работ. Два раза в год (как правило, зимой и летом) происходит сдача сессий. Развитие сферы образования на основе новых прогрессивных концепций, внедрения в учебновоспитательный процесс новейших педагогических технологий и научно-методических разработок, а также использование новых информационно-коммуникационных технологий позволяют организовать заочное обучение как дистанционное.

Дистанционное обучение - это получение образования с помощью интернета и современных информационных и телекоммуникационных технологий. При этом происходит обмен учебной информацией с помощью современных средств на расстоянии. Данный вид обучения расширяет возможности для получения качественного профессионального образования. [1]

Система дистанционного обучения имеет большое количество преимуществ по сравнению со стационарным способом обучения:

- студент сам устанавливает темп изучения учебного материала в зависимости от его личных возможностей, обстоятельств и потребностей;

- он может выбрать любой из курсов обучения, а также самостоятельно планировать время, место и продолжительность занятий;

- географическое положение образовательного учреждения и время суток не ограничивают студента; 